\title{
IN THE SEARCH FOR EFFECTIVE WASTE POLICY: ALIGNMENT OF UK WASTE STRATEGY WITH THE CIRCULAR ECONOMY
}

\author{
Carly A. Fletcher * and Rachel M. Dunk \\ School of Science and the Environment, Manchester Metropolitan University, Manchester, United Kingdom
}
Article Info:
Received:
17 January 2018
Revised:
29 August 2018
Accepted:
5 October 2018
Available online:
23 November 2018
Keywords:
Circular economy
Framework
Content analysis
National strategy
EU waste policy
Brexit

\begin{abstract}
Over-consumption within a linear economy has been recognised internationally as a barrier to sustainability and a major cause of environmental degradation and economic disparity. To address these issues, the transition towards a circular economy (CE) has been advocated. A broad resource efficiency concept, the CE seeks to reduce consumption, encourages the reuse and recycling of materials and products, and encompasses the three pillars of sustainable development; economic prosperity, environmental protection, and social equity. Efforts to implement the CE have seen the introduction of various hierarchies that prioritise the implementation of R-imperatives (such as the ' $3 R s^{\prime}$ of reduce, reuse, recycle). One such example is the waste hierarchy, originally introduced to encourage sustainable waste management and more recently reiterated by the EU Circular Economy Package as a means to stimulate the transition to the CE. Following the development of a CE Framework, this study presents a content analysis of the waste strategies of the four devolved nations of the United Kingdom. Key differences and similarities in the strategies of the four devolved nations are identified and discussed in light of CE aims, core concepts and principles (with particular focus on promotion of the waste hierarchy), enablers, and stakeholder engagement, where Scotland and Wales were found to have the most progressive strategies. This study also considers the potential impact of Brexit, where it is recommended an overarching UK-wide strategy that provides consistent and collaborative long-term objectives is required to replace the overarching objectives previously supplied by the EU policy.
\end{abstract}

\section{INTRODUCTION}

Rising global population and a growing trend towards higher living standards have led to increased depletion of natural resources and environmental degradation due to the linear 'take-make-dispose' model on which economic growth has been built (Moreno et al.,, 2016; Wysokinska, 2016). The need to overcome this unsustainable pattern of consumption has been acknowledged internationally, most notably through the prioritisation of Sustainable Consumption and Production (SCP) within the United Nations 10-year Framework of Programmes (UNEP, 2015), where a key component of SCP is the transition to a Circular Economy (CE).

At its core, the CE is a broad resource efficiency concept (Su et al.,, 2013) that seeks to mimic natural biological systems by continuously recirculating and reprocessing materials and energy (Lieder and Rashid, 2016). As discussed by Winans et al., (2017), the CE model has evolved continuously since the 1970s, building on and encompassing a number of preceding ideas. It is deeply rooted in resource efficiency concepts that advocate moving from end-of-pipe solutions to life cycle and systems thinking. For example, Stahel and Reday-Mulvay's (1976) vision of a 'loop economy' that returns durable products from cradle-to-cradle, and Pearce and Turner's (1990) argument for a shift from a 'resources-products-pollution' to a 'resources-products-regenerated resources' mode. Additionally, it includes the recognition that there are limits to growth (Meadows et al., 1972), and that human industry relies on resources and services provided by the biosphere (industrial ecology) and cannot therefore be considered in isolation from it (Erkman, 1997). Indeed, Murray et al., (2017) argues that rather than promoting biomimicry, the CE should aim to "bio-participate" where actions take place within the existing biosphere.

Despite widespread agreement for the need to transition to a CE, a standardised definition of the CE (or understanding of what transition entails) has been lacking, where this has been attributed to both the evolving nature of the concept and the use of the concept by stakeholders from different disciplinary or industrial backgrounds (Kirchherr 
et al., 2017). Analysis of 114 definitions found that while the CE is often defined using hierarchies of R-imperatives (e.g. the 3 Rs of reduce, reuse and recycle), the systemic change needed to implement the CE is frequently overlooked (Kirchherr et al., 2017). Furthermore, definitions are limited by insufficient linkages to other aspects of sustainable development, primarily focusing on economic prosperity followed by environmental protection, and with very limited consideration of social equity or future generations (Kirchherr et al., 2017). To address this shortcoming, Kirchherr et al., (2017) proposed a standardised definition of the CE as "an economic system that is based on business models which replace the 'end-of-life' concept with reducing, alternatively reusing, recycling and recovering materials in production/distribution and consumption processes, thus operating at the micro level (products, companies, consumers), meso level (eco-industrial parks) and macro level (city, region, nation and beyond), with the aim to accomplish sustainable development, which implies creating environmental quality, economic prosperity and social equity, to the benefit of current and future generations."

Intended to function as a fully regenerative closed ecological-economic system (Lieder and Rashid, 2016), resource use should be reduced by embedding $\mathrm{R}$ - imperatives at all stages of design, production, distribution and consumption (Su et al., 2013; Wysokinska, 2016). Thus, in addition to clean production techniques, maintaining the flow of materials and energy within the CE requires a combination of innovative product design, extended producer responsibility (EPR), new business models, and consumer behaviour change, and hence necessitates stakeholder engagement across the supply chain (EMF, 2015; Lieder and Rashid, 2016; Stahel, 2016; Su et al., 2016; Tukker, 2015; Wysokinska, 2016).

Eco-design and regenerative-design approaches play a critical role, where resources are either designed out through dematerialisation or can be readily regenerated at end of life, and where product and component lifespan is extended through increased durability, repairability, and the standardisation of components (Leider and Rashid, 2016; Wysokinska, 2016). Reuse and regeneration can be further enhanced through EPR and the implementation of reverse cycles within the supply chain, whereby products and materials are returned to the producer to be reused or reprocessed (EMF, 2015; Wysokinska, 2016). Product utility can also be increased by changing the business model in which products are sold and consumed or through consumer reuse (Stahel, 2016). Providing products through service agreements, such as pay-per-use, sees the producer retain responsibility and therefore incentivises resource efficiency and product utility above unit sales (Stahel, 2016; Tukker, 2015). With respect to consumer reuse, the emergence of the 'sharing economy', in which underutilised assets are shared (or re-sold) through peer-to-peer interactions within community-based (online) services, may not only enable more efficient use of products but also deliver economic and social benefits (Cherry and Pidgeon, 2018; Martin, 2016). However, the extent to which these benefits are realised is unclear, with concerns that the sharing econ- omy may lead to increased overall consumption (Cherry and Pidgeon, 2018; Martin, 2016).

The transition to a CE is often viewed as synonymous with or requiring a movement towards 'zero-waste' (e.g. Ghisellini et al., 2016). Zero-waste (ZW) can be defined in various ways including $Z W$ to landfill and $Z W$ emissions to land, sea and air, but generally requires sustainable waste management and increased resource utility (Cole et al., 2014). However, while the two concepts are clearly complementary, they can be viewed as subtly different (Veleva et al., 2017), with implications for policy development for appropriate emphasis. For example, Veleva et al., (2017) argue that ZW approaches focus primarily on recapturing resources from waste streams, reducing consumption, and applying a life cycle approach to product design, whilst the CE extends beyond this by designing out waste and introducing innovative business models and collaborative platforms to continuously reuse materials. The CE also emphasises use of renewable materials and energy and places a stronger emphasis on return of biological nutrients to nature. As such, pursuing ZW might be viewed as incremental continuous improvement, whilst in comparison the CE could be seen as transformative.

Although there is strong agreement regarding the urgent need to shift to more sustainable patterns of consumption and production, limitations of the CE (as described above) and barriers to transition have also been identified. Jawahir and Bradley (2016) argue that while the socio-political dimensions and opportunities of the CE are being pursued and promoted, the technological challenges to implementation are often overshadowed, where they highlight the need to promote innovation and expand thinking to consider multiple, intersecting lifecycles. Similarly, Murray et al., (2017) highlight the risk of unintended consequences, where impacts are transferred due to over simplistic goals that are based on reductionist thinking and mathematical models. Andrews (2015) suggests that the transition towards the CE may be limited due to the presence of materials and products that are difficult to reuse or recycle and a lack of knowledge and understanding of relevant stakeholders. Likewise, Kirchherr et al., (2017) highlight that consumers, and their role as key enablers of the $\mathrm{CE}$, are frequently neglected.

Thus, to aid transition to the $\mathrm{CE}$, the challenge for policy makers is to engage with all stakeholders to reduce consumption, enable and develop new markets, encourage innovation, and promote resource efficiency (Price, 2001; EMF, 2015; Lieder and Rashid, 2016). Three levels of contributing stakeholders should be acknowledged in successful CE policy; micro-level such as individual consumers, designers and producers; meso-level, including community groups, individual sectors and industrial parks; and, macro-level, encompassing cities and regions (including local authorities, national government and regional administrations), co-operative networks and multi-national businesses (Su et al., 2016; Kirchherr et al., 2017). Nevertheless, some have argued that the most important role of overarching strategies and policies is to engage and inspire individuals to consume less, reuse goods, and present high 
quality recyclate when waste is unavoidable (Price, 2001; EMF, 2015).

As previously noted, the R-imperatives are recognised as a building block of the $\mathrm{CE}$, where ranking these imperatives (in order of preference for value retention) within R-hierarchies is viewed as necessary to provide guidance and promote effective implementation of the CE (Kirchherr et al., 2017; Murray et al., 2017). However a recent review of CE literature found significant variation in the number of R-imperatives used (between 3 and 10), the combination of imperatives, choice of terminology, and assigned meanings (38 different R-imperatives were identified with varying definitions), whether or not the imperatives were ranked, and in cases where they were ranked, their relative position (Reike et al., 2018). While efforts have been made to develop nuanced hierarchies employing a high number of R-imperatives, thereby providing an operationalisation principle than maximises resource value retention, inconsistencies remain (Potting et al.,, 2017; Reike et al.,, 2018). Nonetheless, as argued by Kirchher et al., (2017), without the use of R-hierarchies that explicitly identify waste prevention imperatives as the highest priority, the concept of CE could be subverted, resulting in limited and minimal changes when implemented. Furthermore, the introduction of strategies that address current (lower) priorities can lead to 'lock-in', where they lack the flexibility to change in the future and so the emergence of more sustainable strategies is restricted (Foxon, 2002). Perhaps one of the most consistent expressions of an R-hierarchy is the "waste-hierarchy" (4R-imperatives of reduce, reuse, recycle, recover, followed by dispose), introduced as a tool to promote sustainable waste management (Van Ewijk and Stegemann, 2014) and referenced in the definition of the CE proposed by Kirchherr et al., (2017). This hierarchy has been particularly visible over the last ten years, where continual development of European Union (EU) waste policy has repeatedly reiterated the waste hierarchy, including re-casting it as a tool to promote the CE within the EU Circular Economy Package (CEP).

This paper examines the circularity of current waste strategy within the UK. As the UK is currently a member of the EU, a brief review of EU waste policy is presented first, followed by current waste policy in the UK and the potential impact of Brexit. Using an adapted CE-framework, a content analysis is then conducted to assess and compare the four devolved nations in terms of CE aims, core concepts and principles (with a focus on use of the waste hierarchy as an operationalisation principle), enablers, and stakeholder engagement.

\subsection{Abbreviations}

\section{CE: Circular Economy}

CEP: Circular Economy Package (EU)

EFTA: European Free Trade Association

EPR: Extended producer responsibility

EWSR: European Waste Shipment Regulations

EU: $\quad$ European Union

SCP: Sustainable Consumption and Production

ZW: Zero waste

\section{CONTEXT}

\subsection{EU Circular Economy Package}

Already a leader in environmental policy (Wysokinska, 2016), the adoption of the CEP by the EU will introduce new priorities that advocate resource efficiency and initiate the transition towards a CE $(E C, 2017)$. While previous strategies such as the 'Roadmap to a resource efficient Europe' (2011-2013) and 'Towards a circular economy: a zero-waste programme for Europe' (2014-2015) promoted the $C E$, their emphasis remained on the efficient use and management of waste. In contrast, the CEP aims to prioritise the CE and address inherent limitations of previous policy initiatives, including a shift in focus toward full product lifecycle thinking (EC, 2017). Although the CEP does encourage industrial symbiosis and the development of secondary materials markets, it also retains an emphasis on waste management strategies such as reiterating the need to implement the waste hierarchy and revising targets for landfill diversion and recycling (Table 1; EC, 2017; Pomberger et al., 2016).

While full implementation of the waste hierarchy would align with CE ideals, Van Ewijk and Stegemann (2014) and Gharfalkar et al., (2015) argue that the limited specification of prevention, the absence of a distinction between openand closed- loop recycling, and the lack of inclusion of other sectors could constrain dematerialisation and resource effectiveness. Other authors have also argued that too little emphasis is placed on the higher priority R-imperatives. For example, while reducing waste at source is the most effective and efficient CE strategy, the absence of quantitative targets for reduction or reuse can create a perceived policy bias towards recycling and disposal (Mazzanti and Zoboli, 2009; Fischer, 2011). However, it is noted that the CEP is supported by other initiatives such as the "Thematic Strategy on the Sustainable Use of Natural Resources" (EC, 2005), the "SCP Action Plan" (EC, 2008) and the "Integrated Product Policy", which includes elements such as eco-design, eco-labelling, and green public procurement (EC, 2016). In combination, these approaches aim to reduce the environmental impact of resource use while promoting economic growth through improving the environmental performance of goods and services across the full lifecycle and creating sustainable business opportunities (EC, 2005, 2008, 2016). This provides a framework of strategies and policy objectives that individual member states should adhere to, to aid their transition toward a CE.

\subsection{Current UK waste policy}

The multilevel governance character of the EU sees overarching objectives published centrally, with decisions regarding the approaches and instruments used to achieve these objectives resting with the individual member states (Nilsson et al., 2012). There are several reported techniques by which EU policy is transposed into national policy including "copy-out" (using the exact words and phrasing of the EU directive), "gold-plating" (going beyond the minimum stated requirements), and "no gold-plating" (consists of only the minimum requirements; Anker et al., 2015). This degree of member state discretion has led to significant 
TABLE 1: Current EU waste management targets and the proposed amendments set out in the Circular Economy Package (CEP).

\begin{tabular}{|c|c|c|c|c|}
\hline Waste Stream & \multicolumn{2}{|c|}{ Existing Policies and Targets } & \multicolumn{2}{|c|}{ Circular Economy Package Proposals } \\
\hline \multirow[b]{2}{*}{ Municipal Solid Waste } & \multicolumn{2}{|c|}{$\begin{array}{l}\text { Landfill Directive }(E C, 1999) \\
\text { When compared to } 1995 \text { base year, the share of biodegrad- } \\
\text { able municipal waste going to landfill may not be greater } \\
\text { than } 75 \% \text { by } 2006,50 \% \text { by } 2009 \text {, and } 35 \% \text { by } 2016 \text {. }\end{array}$} & \multicolumn{2}{|c|}{$\begin{array}{l}\text { Proposed Amendment (EC, 2018b) } \\
\text { Bans disposal to landfill of separately collected wastes } \\
\text { and extends landfill diversion target to all municipal waste, } \\
\text { where the share of municipal waste sent to landfill is limited } \\
\text { to } 10 \% \text { by } 2035 \text {. }\end{array}$} \\
\hline & \multicolumn{2}{|c|}{$\begin{array}{l}\text { Waste Framework Directive (EC, 2008) } \\
\text { By } 2015 \text {, separate collection shall be set up for at least } \\
\text { paper, metal, plastic and glass. } \\
\text { Preparing for re-use and recycling of } 50 \% \text { of at least paper, } \\
\text { metal, plastic and glass from household and similar sources } \\
\text { by } 2020 \text {. }\end{array}$} & \multicolumn{2}{|c|}{$\begin{array}{l}\text { Proposed Amendment (EC, } 2018 \text { d) } \\
\text { Extends preparation for re-use and recycling to all municipal } \\
\text { waste, with targets of } 55 \% \text { by } 2025,60 \% \text { by } 2030 \text {, and } 65 \% \\
\text { by } 2035 \text {. }\end{array}$} \\
\hline $\begin{array}{l}\text { Construction \& Demolition } \\
\text { Waste }\end{array}$ & \multicolumn{2}{|c|}{$\begin{array}{l}\text { Waste Framework Directive }(E C, 2008) \\
\text { Preparing for reuse, recycling and other recovery such as } \\
\text { backfilling of } 70 \% \text { of non-hazardous construction and demo- } \\
\text { lition waste by } 2020 \text {. }\end{array}$} & \multicolumn{2}{|c|}{$\begin{array}{l}\text { Proposed Amendment (EC, 2018d) } \\
\text { No extension to existing target, but requires introduction } \\
\text { of measures to promote selective demolition and removal } \\
\text { of materials, and to establish sorting systems for at least } \\
\text { wood, mineral fractions (concrete, bricks, tiles and ceram- } \\
\text { ics, stones), metal, glass, plastics and plaster. }\end{array}$} \\
\hline \multirow{7}{*}{ Packaging Waste } & \multicolumn{2}{|c|}{$\begin{array}{l}\text { Packaging Waste Directive }(E C, 1994) \\
\text { By } 200860 \% \text { of packaging waste to be recovered, with a } \\
\text { minimum of } 55 \% \text { and maximum of } 80 \% \text { to be recycled, and } \\
\text { minimum recycling rates for specific materials as follows: }\end{array}$} & \multicolumn{2}{|c|}{$\begin{array}{l}\text { Proposed Amendment (EC, 2018c) } \\
\text { Removes the maximum and extends the minimum recycling } \\
\text { rates for all packaging waste to } 65 \% \text { by } 2025 \text { and } 70 \% \text { by } 2030 \text {, } \\
\text { and extends the targets for specific materials as follows: }\end{array}$} \\
\hline & wood: & $15 \%$ & wood: & $25 \%$ and $30 \%$ \\
\hline & plastics: & $22.5 \%$ & plastics: & $50 \%$ and $55 \%$ \\
\hline & metals: & $50 \%$ & ferrous metals: & $70 \%$ and $80 \%$ \\
\hline & & & aluminium: & $50 \%$ and $60 \%$ \\
\hline & glass: & $60 \%$ & glass: & $70 \%$ and $75 \%$ \\
\hline & paper and board: & $60 \%$ & paper and board: & $75 \%$ and $85 \%$ \\
\hline
\end{tabular}

differences in national implementation of resource and waste policy (Garcia Quesada, 2014).

Over the last two decades, UK environmental legislation has been largely shaped by EU directives, where it is a notable feature of UK waste policy that secondary legislation is used extensively to transpose EU law into domestic law (Scotford and Robinson, 2013). Indeed, EU legislation has provided momentum to improve waste management in the UK, lifting it above the national party politics that previously hindered the development and implementation of a long-term strategy (UKELA, 2016; BP Collins, 2016). During this time, the UK has introduced fiscal instruments such as the landfill tax, extended separate recyclate collections, and increased exports of refuse derived fuel, all of which have aided a transition away from high landfill dependency (Pomberger et al., 2016). However, due to a plateau in progress potentially caused by the "no gold-plating" approach of transposition, the development of new measures that manage resources rather than waste are now required to maintain the momentum of positive change.

\subsection{Impact of Brexit}

Although the UK is currently negotiating its withdrawal from the EU (termed "Brexit"), it is expected that the CEP will be transposed into UK law. Once the UK has fully withdrawn from EU membership it will no longer be obligated to transpose or adhere to EU directives. However, while the official withdrawal date is the 29th March 2019, a transition period extending to 31 st December 2020 has recently been agreed, during which EU law "shall be applicable to and in the UK" (EC, 2018a). Hence, as the amendments to existing directives proposed under the CEP (EC, 2018b-d) are expected to enter into force in 2018 and require transposition within eighteen months, the UK will be obligated to transpose them. As noted above, current UK environmental law is highly dependent on that of the EU, where the UK will convert the existing body of EU environmental law into domestic law on 'exit day' through a blanket transposition under the Withdrawal Bill (European Union (Withdrawal) HL Bill (2017-19) 79). However, after the end of the transition period the UK would not be obligated to adhere to the CEP, where UK governments could act to repeal or amend the transposed domestic law (BP Collins, 2016; UKELA, 2017). This leads to the question of how UK waste and resource management will develop in the absence of the long-term vision and strategy provided by the EU. Current commentary on post-Brexit waste policy suggests that in the short term the UK would continue to apply existing EU legislation and strategy (Burges Salmon, 2016; BP Collins, 2016). However, in the medium to long term it is difficult to predict whether successive UK governments would maintain compliance with current and successive EU legislation, look to go beyond them, or maintain the current status quo, with the risk of being left behind (Burges Salmon, 2016).

Other potential implications of Brexit for waste management in the UK and for other EU member states have also been highlighted, particularly in relation to cross border movement of wastes (House of Lords, 2017; UKELA, 2016, 2017). Gibraltar (a British overseas territory) is completely reliant on Spain for its waste management (both collection and treatment) and the Republic of Ireland exports $40 \%$ of its hazardous waste to the UK due to the lack of capacity in local treatment facilities (McGlone, 2018). The UK also 
exports a significant tonnage of waste derived materials to other EU member states. Indeed, exports of waste derived fuel to European countries have increased from zero in 2010 to over 3 million tonnes in 2016 (DEFRA, 2017; UKELA, 2016). Likewise, due to limited domestic processing capacity, exports of recyclable materials have risen from around 8 million tonnes in 2002 to around 14 million tonnes in 2015 (DEFRA, 2017), where around a quarter of sorted waste materials are sent to northern European countries which have an overcapacity in processing facilities (House of Lords, 2017).

Post-Brexit, the movement of waste between the UK and EU countries must adhere to the European Waste Shipment Regulations (EWSR) (EC, 2006). Under the EWSR, the import of waste is allowed from a third (non-EU) country that is a party to the Basel Convention on the Control of Transboundary Movement of Hazardous Wastes and their Disposal (the Basel Convention) (UNEP, 1989). However, export of waste for disposal or mixed municipal waste for recovery to a third country is prohibited, unless it is both a party to the Basel Convention and a member of the European Free Trade Association (EFTA). Furthermore, imports and exports of waste between the UK and the EU will most likely become subject to border checks and depending on the outcome of negotiations could become subject to tariffs (EC, 2018a), with the risk that such shipments become financially unviable (House of Lords, 2017).

The future status of the UK with respect to the Basel Convention (an international agreement ratified jointly by the EU and the UK) is uncertain. Analysis indicates that the effect of Brexit on such "mixed agreements" is somewhat ambiguous, with some analysts concluding that they will have to be renegotiated, and others adopting the position that the UK will remain bound by them post-Brexit (UKELA, 2017). Nonetheless, while the status of mixed agreements remains to be clarified, the UK government has expressed the view that the UK is a party in its own right and will continue to be bound by such agreements post-Brexit (House of Lords, 2017).

The UK joining the EFTA post-Brexit has been posited as a potential option, in which case waste exports from the EU to the UK could continue with respect to EWSR, however access to the single market (so as to avoid import/export tariffs) would require the UK to continue to adopt the relevant evolving EU acquis. Furthermore, for any recovery of waste generated by EU member states and exported to the UK, the EU member state will only be able to count that waste towards fulfilment of EU targets if the treatment conditions are equivalent to the requirements of applicable EU directives (EC, 2018d).

All of the above Brexit related uncertainties regarding the future of waste management in the UK are further complicated by the differing positions of the devolved nations. The devolution of power in the UK allows the four home nations (England, Scotland, Wales and Northern Ireland) to manage waste and resources within their own boundaries while contributing to overall UK objectives. This has led to the introduction of different strategies by the four nations. Indeed, based on an evaluation of primary and secondary environmental legislation, Scotford and Robinson (2013) argue that Wales and Scotland are providing the most innovative legislation developments within the UK.

\section{METHODS}

A content analysis was used to assess the current waste management strategies of the four devolved administrations of the UK home nations. Based on a CE framework adapted from Kirchherr et al., (2017) in light of the literature reviewed above, the main themes explored within the analysis were; CE aims, core concepts and principles, enablers, and stakeholder engagement, with a particular focus on the promotion of the waste hierarchy as an operationalisation principle and the inclusion of stakeholders. The analytical framework is presented in Figure 1, where the correspondence between the waste hierarchy and a more nuanced hierarchy of R-imperatives is presented in Figure 2. Here the R-hierarchy is synthesised from Potting et al., (2017) and Reike et al., (2018), and modified to align with the EU waste-hierarchy, such that repair without change in ownership (by a consumer or under a product-service agreement) to extend product life is viewed as a waste prevention measure (as the product is not discarded and has not become a waste). The role of re-servitisation and re-modelling business and actions that can be undertaken by consumers (italic text) as enablers of high priority R-imperatives are also highlighted.

Content analysis has been widely employed as both a qualitative and a quantitative method across a range of policy areas including: health (e.g. Lemiengre et al.,, 2008), environment (e.g. Maczka et al.,, 2016), serious crime (e.g. Paoli et al.,, 2017), procurement (e.g. Testa et al.,, 2016), and cleaner production (e.g. Peng and Liu, 2016). It provides a simple yet flexible method to describe and quantify phenomena, analyse written, verbal or visual communication, and enhance the understanding of data through the exploration of theoretical ideas (Elo and Kyngäs, 2008). It also allows the inclusion, comparison and corroboration of large volumes of textual data from different sources (Elo and Kyngäs, 2008). To do this and ensure reliability, analysis should be objective, systematic and quantitative whereby categories of analysis are precisely defined, and the inclusion/exclusion of documents is based on consistent rules (Testa et al.,, 2016).

Taking these factors into account, the most recent waste management strategies published by each of the home nations were selected for inclusion in this study:

- England: "Waste Management Plan for England" (DEFRA, 2013);

- Scotland: "Scotland's Zero Waste Plan" (Natural Scotland, 2010);

- Wales: "Towards Zero Waste - One Wales: One Planet" (WAG, 2010);

- Northern Ireland: "Delivering Resource Efficiency” (DoE, 2013).

Only main body text was analysed with all other text (front matter, legends, footnotes, etc.) excluded. To ensure rigour, two researchers assessed all documents, with points of ambiguity or disagreement discussed and clari- 
Aims

\begin{tabular}{|c|c|}
\hline \multicolumn{2}{|c|}{ Sustainable Development } \\
\hline Economic prosperity & Environmental protection \\
\hline Social equity & Future generations \\
\hline
\end{tabular}

\section{Core concepts and principles}

\begin{tabular}{|c|}
\hline Resource efficiency \\
\hline Life cycle thinking \\
\hline $\begin{array}{c}\text { Sustainable consumption } \\
\text { and production (SCP) }\end{array}$ \\
Limits to growth / \\
$\begin{array}{c}\text { decoupling economic growth } \\
\text { and societal wellbeing } \\
\text { from resource use }\end{array}$ \\
\hline $\begin{array}{c}\text { Systemic (transformational) } \\
\text { change and avoiding lock-in }\end{array}$ \\
\hline
\end{tabular}
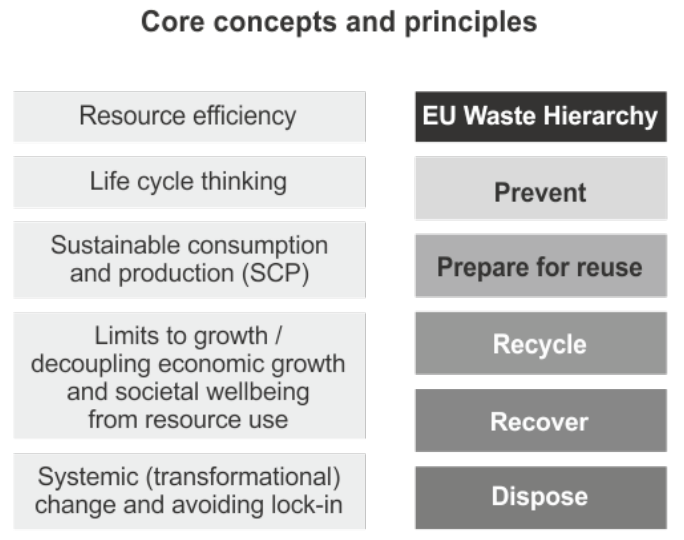

Enablers

\begin{tabular}{|l|l|}
\hline \multicolumn{2}{|c|}{ Introduce measures and instruments to promote: } \\
\hline Re-servitisation \& re-modelling business & Consumers as enablers of the CE \\
\hline Development of secondary markets & Technological innovation \& investment \\
\hline
\end{tabular}

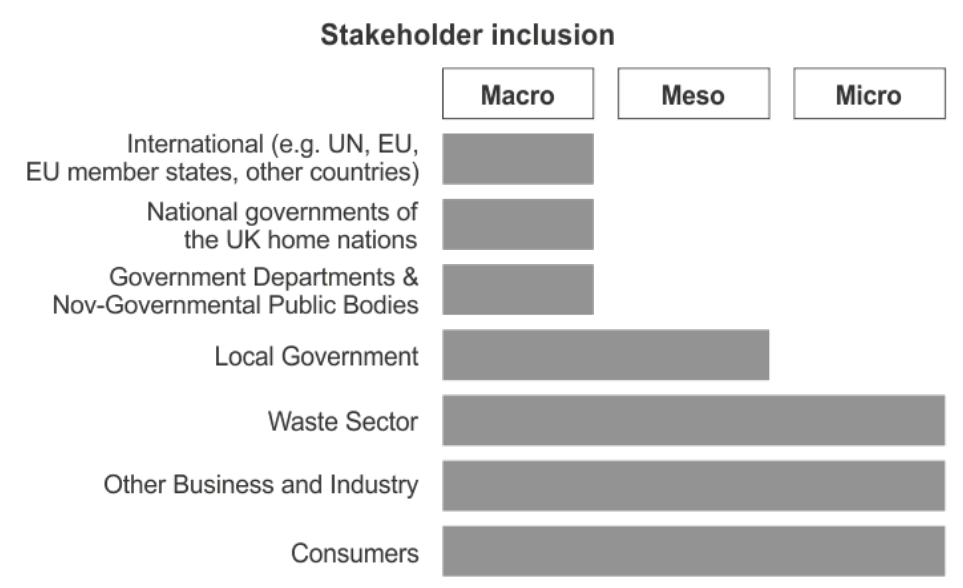

FIGURE 1: Circular Economy Framework (adapted from Kirchherr et al.,, 2017).

fied. The use of CE or ZW terminology, the broader context within which waste management was positioned, and the overarching approach of each strategy document was first explored. This was supported by the compilation of national statistics regarding population and rates of waste generation, recycling and landfilling (based on DEFRA, 2018). Using a basic automated keyword search, and manual analysis to ensure complete coverage, the inclusion of CE aims, core concepts and principles, and enablers was evaluated (Corbin and Strauss, 2008; Welsh, 2002). Waste hierarchy R-imperatives and stakeholder terms were also quantified on both a total document and per paragraph basis, and documents ranked (based on per paragraph counts) to compare incorporation of waste hierarchy R-imperatives and stakeholder engagement. Additionally, the responsibilities of each stakeholder group were noted and compared.

\section{RESULTS AND DISCUSSION}

\subsection{Context and overarching vision}

Table 2 presents a summary of the waste strategy document for each home nation, including the volume of text analysed, the context, and the overall vision, alongside population and waste statistics for the document year and for 2016 (Defra, 2018).

\subsubsection{England}

The stated aim of the Waste Management Plan for England is to work towards a ZW economy as part of the transition to a sustainable economy. Here, a ZW economy is defined as one within which material resources are reused, recycled or recovered wherever possible and only disposed of as the option of last resort, where the need to reduce waste generation and ensure all materials are fully valued during their productive life (in addition to at end of life) are also recognised. However, the substance of the plan focuses primarily on minimising the environmental and human health impact of waste generation and management, where this is achieved by supporting local authorities (and waste management companies) to prioritise recycling and recovery of waste materials. While it highlights the role of ZW initiatives and advocates lifecycle thinking and closed loop approaches, it provides little more than rhetoric regarding these ideas. For example, although it does imply that resources should be used efficiently, rather than introducing governmental drivers to achieve this, it places the responsibility on business and industry for creating more goods and services with fewer resources.

\subsubsection{Scotland}

Scotland's Zero Waste Plan defines a ZW Scotland as one that makes the most efficient use of resources by minimising demand on primary resources and maximising the reuse, recycling and recovery of resources instead of treating them as wastes. It frames waste management strategy within the context of economic growth and climate change, where resources are managed efficiently, economic opportunities are sought (and capitalised upon), waste materials are given a value, and greenhouse gas emissions are reduced. To do this, it advocates a transition away from a linear economy, long-term policy stability, and effective resource use. It also acknowledges the role of consumer behaviour, asking individuals and businesses to recognise and take responsibility for their actions. It recognises the need for continued waste management strategies for the foreseeable future and promotes the reuse, recycling and recovery of resources from waste in line with the waste hierarchy. 


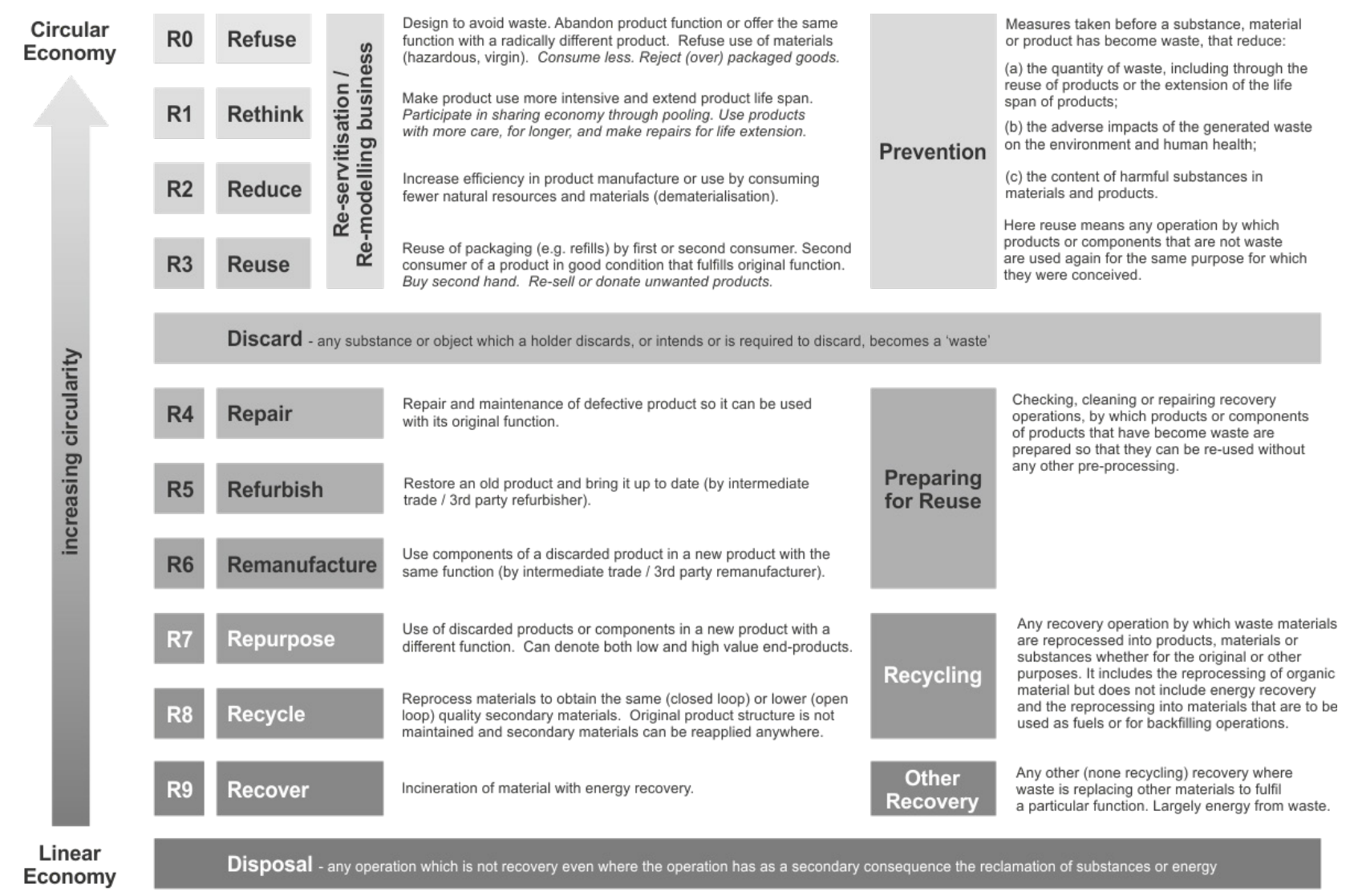

\begin{tabular}{c|ll}
$\begin{array}{c}\text { Re-circularising } \\
\text { the economy }\end{array}$ & Remine Urban or landfill mining - the retrieval of materials after landfilling.
\end{tabular}

FIGURE 2: Alignment of the EU Waste Hierarchy with the R-Imperatives (R0 - R10) needed in the transition to the circular economy (R-imperatives synthesised from Potting et al.,, 2017 and Reike et al.,, 2018).

\subsubsection{Wales}

Towards Zero Waste - One Wales: One Planet defines ZW as an aspirational end-point where all waste that is produced is reused or recycled as a resource, without the need for any landfill or energy recovery. It frames waste management strategy in the broader context of social justice, cultural legacy, climate change and limited resources. It aims to create a pathway to where resource use is within environmental limits, society and culture prosper, and human well-being is maximised. To do this, it advocates SCP, optimisation of material utilisation, and reduced dependence on primary resources. It promotes a long-term framework that requires the engagement of citizens, business and industry. Citizens are asked to rethink and reconsider consumption patterns, and to become a recycling society, whilst business and industry are asked to use alternative materials, employ Integrated Product Policy and reduce associated emissions. It acknowledges the continued production of some waste and so advocates enhanced action on waste prevention, maximised recycling and near $\mathrm{ZW}$ to landfill. It also notes the requirement to manage legacy wastes.

\subsubsection{Northern Ireland}

The Delivering Resource Efficiency strategy aims to set a direction towards treating waste as a resource and using it more efficiently. This is positioned within the EU objective of moving towards a CE, and although no definition of a $\mathrm{CE}$ is given, it is noted that it requires a greater focus on waste prevention followed by an increase in recycling. The strategy is positioned in the context of economic growth, whereby sustainable waste management can promote green jobs, maximise opportunities, and contribute to a low carbon, CE It identifies the need for both socially responsible economic growth and global economic transformation to address depletion of finite natural resources and climate change. To do this, it advocates the implementation of the waste hierarchy, recognition of waste as a resource, use of environmentally friendly technology and behaviours, and increased integrated support across sectors and between stakeholders.

\subsection{CE aims, core concepts and principles, enablers and stakeholders}

Development of the CE framework allowed the systematic, yet simple, assessment of documents. When CE aims, core concepts and principles (including promotion of the waste hierarchy), enablers, and the inclusion of stakeholders were considered, both similarities and substantial differences were found between the waste strategies of the UK home nations. 
TABLE 2: Summary of UK home nations population, waste generation and management statistics, and national waste strategy documents.

\begin{tabular}{|c|c|c|c|c|c|c|c|c|}
\hline \multirow[b]{2}{*}{ Year of statistics } & \multicolumn{2}{|c|}{ England } & \multicolumn{2}{|c|}{ Scotland } & \multicolumn{2}{|c|}{ Wales } & \multicolumn{2}{|c|}{ Northern Ireland } \\
\hline & 2013 & 2016 & 2010 & 2016 & 2010 & 2016 & 2013 & 2016 \\
\hline Population & $53.9 \mathrm{~m}$ & $55.3 \mathrm{~m}$ & $5.3 \mathrm{~m}$ & $5.4 \mathrm{~m}$ & $3.0 \mathrm{~m}$ & $3.1 \mathrm{~m}$ & $1.8 \mathrm{~m}$ & $1.9 \mathrm{~m}$ \\
\hline Waste generation ${ }^{(i)}$ & $400 \mathrm{~kg}$ & $410 \mathrm{~kg}$ & $490 \mathrm{~kg}$ & $440 \mathrm{~kg}$ & $450 \mathrm{~kg}$ & $420 \mathrm{~kg}$ & $430 \mathrm{~kg}$ & $450 \mathrm{~kg}$ \\
\hline Recycling rate & $44.2 \%$ & $44.2 \%$ & $32.5 \%$ & $42.8 \%$ & $44.0 \%$ & $56.7 \%$ & $41.5 \%$ & $43.0 \%$ \\
\hline Landfill rate $e^{(i)}$ & $25 \%$ & $21 \%$ & $41 \%$ & $30 \%$ & $33 \%$ & $16 \%$ & $24 \%$ & $27 \%$ \\
\hline Strategy document & \multicolumn{2}{|c|}{$\begin{array}{l}\text { Waste Management Plan } \\
\text { for England }\end{array}$} & \multicolumn{2}{|c|}{$\begin{array}{l}\text { Scotland's Zero } \\
\text { Waste Plan }\end{array}$} & \multicolumn{2}{|c|}{$\begin{array}{l}\text { Towards Zero Waste } \\
\text { One Wales: One Planet }\end{array}$} & \multicolumn{2}{|c|}{$\begin{array}{l}\text { Delivering Resource } \\
\text { Efficiency }\end{array}$} \\
\hline Total pages & \multicolumn{2}{|c|}{42} & \multicolumn{2}{|c|}{59} & \multicolumn{2}{|c|}{92} & \multicolumn{2}{|c|}{68} \\
\hline Pages analysed & \multicolumn{2}{|c|}{38} & \multicolumn{2}{|c|}{46} & \multicolumn{2}{|c|}{59} & \multicolumn{2}{|c|}{51} \\
\hline Paragraphs analysed & \multicolumn{2}{|c|}{194} & \multicolumn{2}{|c|}{288} & \multicolumn{2}{|c|}{357} & \multicolumn{2}{|c|}{374} \\
\hline Words analysed & \multicolumn{2}{|c|}{10,943} & \multicolumn{2}{|c|}{13,746} & \multicolumn{2}{|c|}{13,768} & \multicolumn{2}{|c|}{19,604} \\
\hline CE Terminology & \multicolumn{2}{|c|}{ zero waste } & \multicolumn{2}{|c|}{ zero waste } & \multicolumn{2}{|c|}{ zero waste } & \multicolumn{2}{|c|}{ circular economy } \\
\hline Context & \multicolumn{2}{|c|}{$\begin{array}{l}\text { Minimise environmental \& } \\
\text { human health impacts }\end{array}$} & \multicolumn{2}{|c|}{$\begin{array}{l}\text { Economic growth \& address- } \\
\text { ing climate change }\end{array}$} & \multicolumn{2}{|c|}{$\begin{array}{c}\text { Social \& cultural justice, } \\
\text { climate change \& limited } \\
\text { resources }\end{array}$} & \multicolumn{2}{|c|}{ Economic growth } \\
\hline Approach & \multicolumn{2}{|c|}{$\begin{array}{c}\text { Supports local authorities, } \\
\text { highlights zero waste initia- } \\
\text { tives, and advocates lifecycle } \\
\text { thinking }\end{array}$} & \multicolumn{2}{|c|}{$\begin{array}{c}\text { Advocates long-term } \\
\text { policy stability and effective } \\
\text { resource use, acknowledges } \\
\text { role of consumer behaviour } \\
\text { and notes need for continued } \\
\text { waste management }\end{array}$} & \multicolumn{2}{|c|}{$\begin{array}{l}\text { Highlights that resource use } \\
\text { should be within environmen- } \\
\text { tal limits. Engages citizens, } \\
\text { business \& industry, and } \\
\text { notes legacy wastes }\end{array}$} & \multicolumn{2}{|c|}{$\begin{array}{l}\text { Advocates implementation } \\
\text { of waste hierarchy, recog- } \\
\text { nises waste as a resource, } \\
\text { and calls for increased inte- } \\
\text { gration and support across } \\
\text { sectors and stakeholders }\end{array}$} \\
\hline
\end{tabular}

(i) Municipal waste generation per capita per year (ii) Biodegradable municipal waste disposed to landfill as a \% of the 1995 baseline.

\subsubsection{CE aims}

All four documents made reference to economic prosperity combined with some other dimension(s) of sustainable development, variously referring to a 'zero waste economy' and a 'sustainable economy' (England, Scotland and Wales), a 'low carbon economy' and a 'green economy' (Scotland, $\mathrm{NI}$ ) and a 'prosperous society' characterised by full employment and high value green jobs (Wales). However, the extent to which environmental quality, social equity, and future generations were considered varied significantly.

With respect to environmental issues, all four documents referred to environmental protection, with a strong emphasis on reducing climate change impacts. Regarding environmental targets and ongoing assessment of strategies, Scotland and Wales were the most progressive, going beyond the weight-based indices used within EU policy by adopting more challenging targets measured a carbon footprint based metric (Scotland) and ecological footprinting (Wales). While NI mentioned carbon footprinting, like England it did not introduce any new targets or metrics to measure improvements.

While all four documents referred to safeguarding human health, and Scotland and NI made some reference to social benefits and well-being, the emphasis was less than that placed on environmental protection. Wales was the only exception to this, with directly comparable prominence of environmental and social aspects of the $C E$, , linking economic and social development with environmental quality, well-being, social justice and equality of opportunity.

All four documents made some reference to shaping the future (through decisions made now) and/or future waste management needs, where Scotland, Wales and $\mathrm{NI}$ also made specific reference to future generations. Wales had the strongest consideration of future societal needs (as indicated by the title of the strategy document), where the concept of living within environmental limits explicitly incorporates the time dimension so as to ensure sufficient resources are available to achieve a better quality of life for both present and future generations.

\subsubsection{Core concepts and principles}

All four documents included multiple references to resource efficiency, where the emphasis placed on this concept was comparable across Scotland, Wales and NI, but significantly weaker for England. Scotland and Wales clearly identified the need for large-scale changes to achieve their objectives (including changes to attitudes and behaviours, and acceptance of change), highlighting the role of policy and the public sector in driving this change. In comparison, $\mathrm{NI}$ made limited reference to the scale of change (although the need for behavioural change and the role of Government leadership in maintaining the pace of change were touched on), while England made no reference to the scale or type of change needed. Inclusion of other core concepts was variable and limited. Only England and NI made explicit reference to decoupling economic growth from resource use, only Wales recognised limits to growth, and only Wales and $\mathrm{NI}$ cited the need for SCP. While Wales and NI made multiple references to the need for life cycle thinking and approaches, England and Scotland made only one reference each. In the case of England this was simply to note that departure from the waste hierarchy could be justified by lifecycle thinking (rather than advocating lifecycle thinking as an underpinning concept to delivering resource efficiency). 


\subsubsection{Promotion of the Waste Hierarchy as an operationali- sation principle}

Figure 3 presents the occurrence of terms associated with waste hierarchy categories within the waste strategy documents of the UK home nations on both an absolute and per paragraph basis.

While occurrence of the waste hierarchy categories differed widely between the four documents on an absolute basis, frequency counts were more comparable on a per paragraph basis. Overall, the implementation of the full waste hierarchy across all documents is considered to reflect EU waste policy, with some differences in relative emphasis relating to the approach to transposition adopted by England and $\mathrm{NI}$ on one hand ("no gold-plating", reactive) and Scotland and Wales on the other ("gold-plating", proactive).

Recycling strategies (material recovery, anaerobic digestion, and composting) were dominant within all four documents, where this national policy emphasis on recycling is likely driven by EU policy and targets that focus on recycling and landfill diversion (Mazzanti and Zoboli, 2009; Fisher, 2011).

Prevention strategies were the second most frequently cited in all documents. It is noted that differences in the counts of prevention terms will to some extent reflect the scope of the waste strategies, where England and Scotland both elected to develop separate waste prevention plans and therefore provided only an overview of intended prevention activities within the analysed documents. Nonetheless, inferences can be drawn from the presence or absence of any reference to different prevention imperatives and activities. Furthermore, it is noted that the separate consideration of waste prevention strategies may have unintended consequences arising from a lack of joined up thinking between waste prevention and waste management activities.

The majority of the prevention terms counted made general reference to the need to reduce waste and mirrored the terminology employed by EU policy. While all four documents made some reference to activities associated with R0-R2 (Refuse, Rethink, Reduce), there was a much stronger emphasis on these imperatives in the Welsh document (particularly with respect to product design and the use of recycled materials), and this was also the only strategy to note the role of consumers (in buying less). Likewise, only Wales and Scotland included R3 (Reuse), and only Wales included re-servitising and re-modelling business.

The least priority was given to "Recover" terms in all documents except Scotland (where it ranked fourth ahead of disposal). However, reference to incineration within the Scottish document was found to be in conjunction with a potential ban on incineration, where the context was to ensure strategies were moved further up the waste hierarchy (not just from disposal to incineration).

The use of continued disposal was found to be a higher priority for the English document (ranked third within this document) when compared with Wales and NI, where it ranked fourth and Scotland where it was given least priority. Interestingly, it is noted that when counts included reference to landfill diversion, the majority of mentions in the Scotland (77\%), Wales (56\%) and NI (59\%) documents were with respect to the latter, whilst in the English document the majority of mentions (66\%) were concerned the continued use of landfill.

As noted by Reike et al (2018) it is common to find within CE literature the use of identical terms with different meanings. In this analysis, particularly when considering the waste hierarchy, terms were found to have unclear

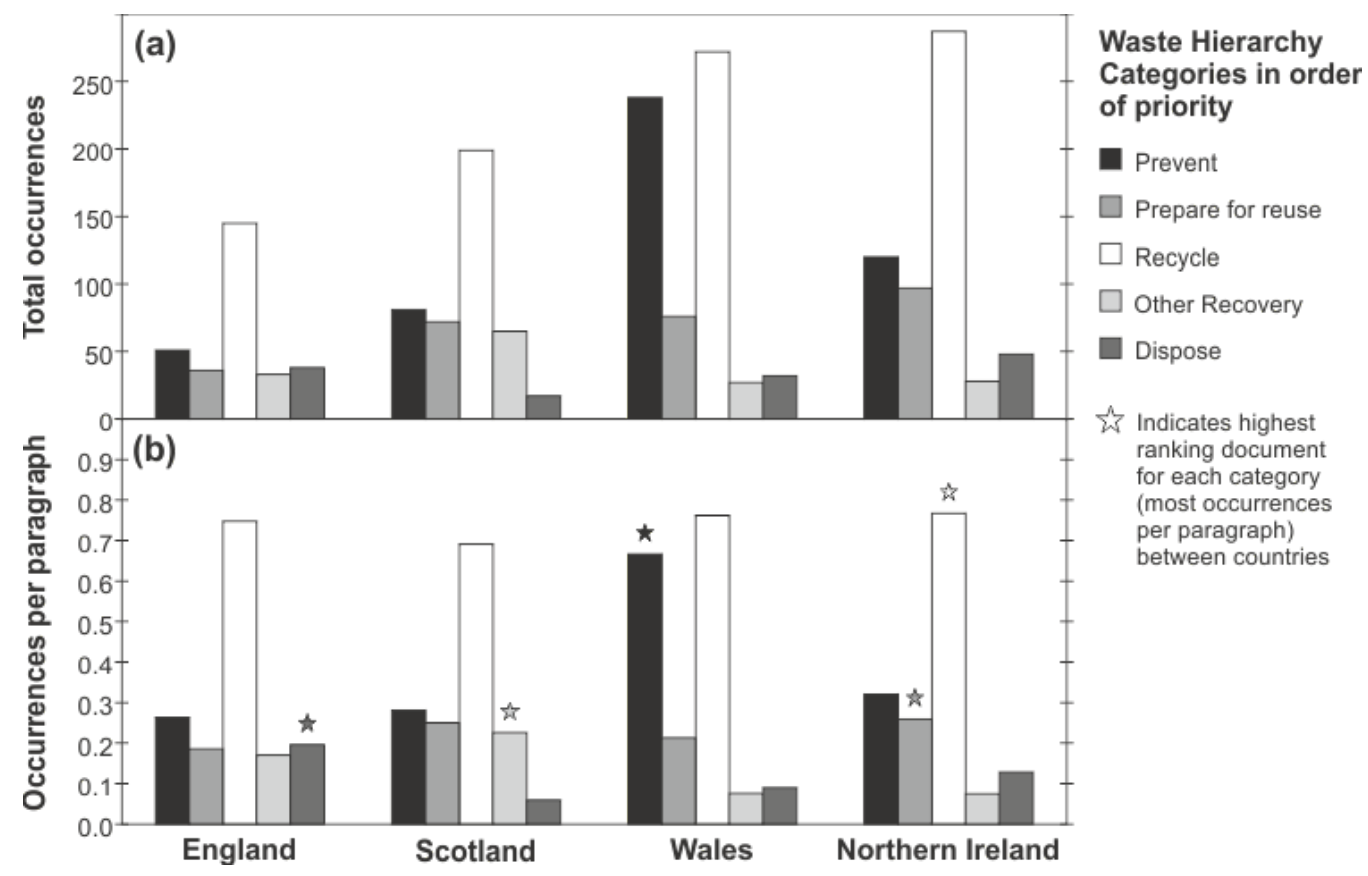

FIGURE 3: Representation of waste hierarchy categories in the waste strategy documents of the UK home nations on (a) a total occurrences basis and (b) an occurrences per paragraph basis. 
meanings. For example, incineration was often referred to without specifying whether it was "with energy recovery" or "without energy recovery" with the former being classified as a recovery term and the latter a disposal term. Other terms were found to cross the boundaries of R-imperatives, for example reuse could be classified under "Reduce" or "Preparation for reuse". While efforts were made to decipher the correct meaning of terms from their context and / or position within the text, this has been acknowledged as a limitation of the framework.

\subsubsection{Enablers and stakeholder engagement}

Comparison of the four documents found variation in the dominant types of enabling measures and instruments employed to drive market changes. While all four documents made some reference to investment, other fiscal incentives/disincentives, green procurement, extended producer responsibility, and the use of voluntary agreements and standards, the relative emphasis differed. Scotland had a strong emphasis on investment, England dominantly referred to EPR followed by investment, Wales promoted the use of green procurement followed by EPR, while NI focused on voluntary agreements / standards and EPR. Furthermore, Wales, and to a lesser extent Scotland and $\mathrm{NI}$, encouraged the development of markets for recyclates and reuse. With respect to measures that addressed consumer behaviour, England was found to be severely lacking. In comparison, Scotland, Wales and NI all promoted the use of education, communication, and consumer engagement and awareness campaigns to change attitudes. These strategies also incorporated measures that required the involvement of other sectors as well as the waste management industry.

Figure 4 presents the occurrence of terms associat- ed with stakeholder categories within the waste strategy documents of the UK home nations on both an absolute and per paragraph basis, where the responsibilities identified for each stakeholder group with respect to policy instruments and feedback mechanisms are summarised in Tables 3-6 for each of the home nations.

Substantive differences were found between the four documents with respect to the engagement of different stakeholder groups. While, England and NI tended to focus on Macro-level stakeholders, particularly those concerned with cities and regions, Wales and Scotland also placed equal emphasis on micro-level (e.g. consumers, producers, designers) and meso-level stakeholders (e.g. sectors, community groups). In light of the argument made by Su et al (2013), Wales and Scotland would be the most successful in implementation of the CE as they include all three levels of stakeholders.

Notable comparisons include the similar prominence of national stakeholders in all four documents. This is expected given the nature of the documents (i.e. published by the devolved governments and being primarily concerned with domestic strategy). While there was differing prominence, the responsibilities of GD/NGPB and International stakeholders were similar, reflecting the former's role as regulators to ensure compliance and issue sanction where necessary and the latter's role to provides and enforce overarching objectives and targets. With respect to international stakeholders, England and NI were found most likely to engage, this being due to existing waste export routes (England) and the presence of a land border with the Republic of Ireland together with ambitions of an all-island waste strategy in NI. Scotland and Wales also referred to using their influence with national and international stakeholders to shape future goals.

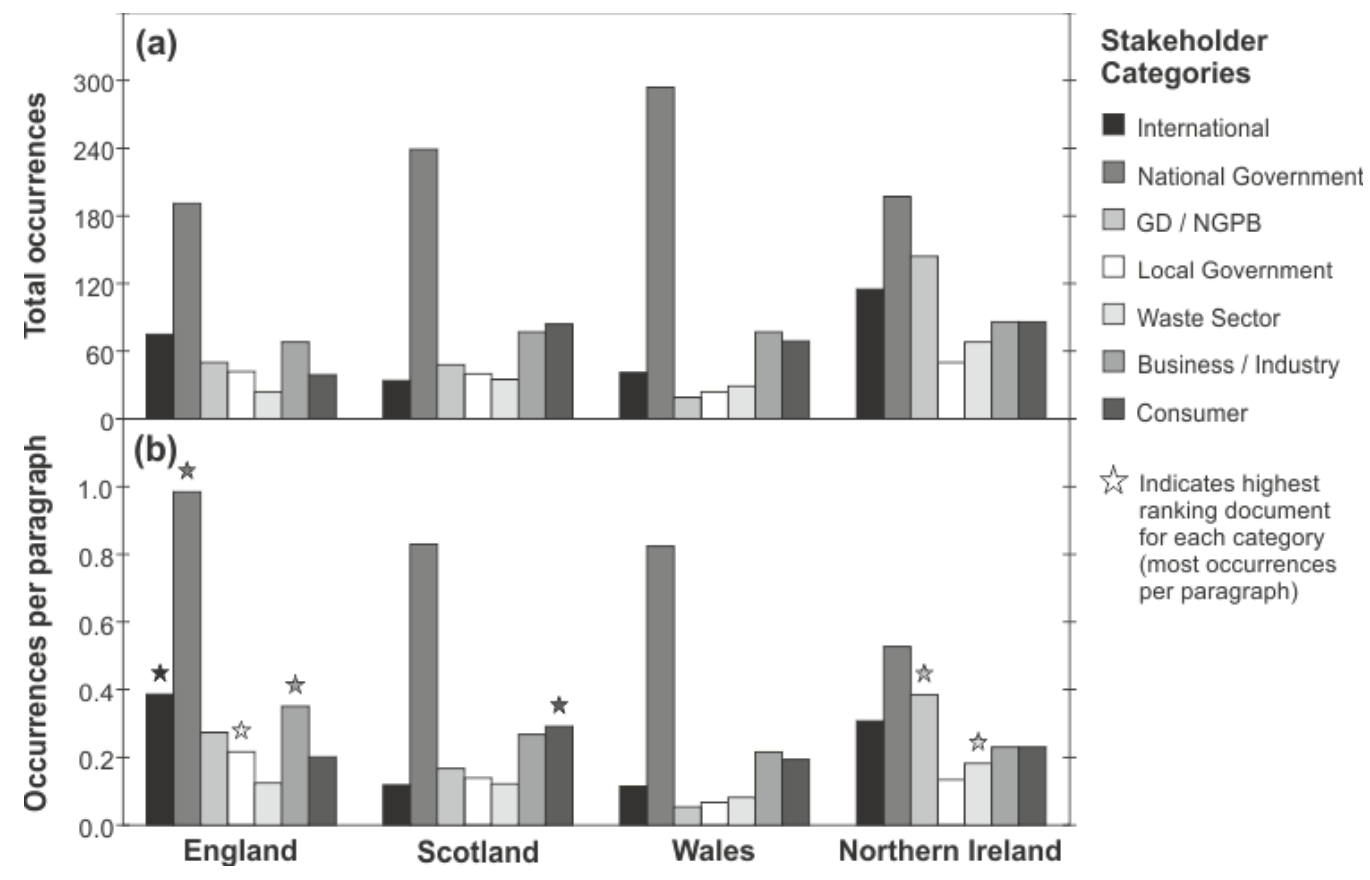

FIGURE 4: Representation of stakeholder categories in the waste strategy documents of the UK home nations on (a) a total occurrences basis and (b) an occurrences per paragraph basis. 
TABLE 3: Stakeholder responsibilities within the Waste Management Plan for England.

\begin{tabular}{|c|c|}
\hline Stakeholder & Responsibilities \\
\hline International & $\begin{array}{l}\text { Set overarching legislation and objectives. Introduce broad programmes to assist with meeting objectives. Require the collection } \\
\text { of data to assess progress. }\end{array}$ \\
\hline National & $\begin{array}{l}\text { Transpose international legislation into national objectives. Set targets, provide support and guidance. Encourage sustainable think- } \\
\text { ing within resource and waste management. Produce quality standards for recycled materials. Identify suitable locations for future } \\
\text { facilities. Monitor and review progress. Provide information and data to other stakeholders. Drive behaviour change }\end{array}$ \\
\hline $\begin{array}{l}\text { Government Depart- } \\
\text { ments \& Non-Gov. } \\
\text { Public Bodies }\end{array}$ & $\begin{array}{l}\text { Implement international and national legislation and policy. Provide funding for schemes. Organise voluntary sector agreements. } \\
\text { Distribute environmental permits. Conduct routine inspections. Provide advice and guidance on the of waste hierarchy strategies } \\
\text { and support inter-stakeholder collaboration. Provide data and evidence regarding current and future waste management activities. } \\
\text { Initiate and/or respond to consultations. }\end{array}$ \\
\hline Regional & $\begin{array}{l}\text { Obligated to implement national legislation, provide waste collection services, and support businesses in meeting their responsibil- } \\
\text { ities. Work in partnership with the waste sector to ensure full and efficient waste services. Record and report waste data and illegal } \\
\text { activity. Provide evidence to consultations. }\end{array}$ \\
\hline Waste Sector & $\begin{array}{l}\text { Adhere to national and international legislation and relevant environmental permit conditions. Where appropriate, develop actions to } \\
\text { meet quality standards and change behaviours to contribute to national objectives. Obligated to provide waste collection services } \\
\text { that are regular, efficient and affordable, working in partnership with local authorities and other regional stakeholders. Contribute to } \\
\text { future waste strategy by providing evidence regarding current activities and responding to consultations. }\end{array}$ \\
\hline $\begin{array}{l}\text { Other Business \& } \\
\text { Industry }\end{array}$ & $\begin{array}{l}\text { Adhere to national and international legislation, meet sector specific targets, participate in voluntary agreements, and provide pri- } \\
\text { vate financial initiatives. Supported in recognising and capitalising on resource efficiency opportunities and encouraged to incorpo- } \\
\text { rate sustainable thinking into product/service design. Contribute to future waste strategy by providing evidence regarding current } \\
\text { activities and responding to consultations. }\end{array}$ \\
\hline Consumers & $\begin{array}{l}\text { Provide evidence on current waste management activities and can respond to consultations. It is acknowledged that consumers are } \\
\text { the main contributors to waste generation and that a change in behaviour would contribute to national objectives; however, they are } \\
\text { not held responsible or accountable by any policy mechanism. }\end{array}$ \\
\hline
\end{tabular}

TABLE 4: Stakeholder responsibilities within Scotland's Zero Waste Plan.

\begin{tabular}{|c|c|}
\hline Stakeholder & Responsibilities \\
\hline International & $\begin{array}{l}\text { Set overarching legislation and objectives. Introduce broad programmes to assist with meeting objectives. Promote the waste } \\
\text { hierarchy and high-quality recycling. Require the collection of data to assess progress. }\end{array}$ \\
\hline National & $\begin{array}{l}\text { Introduce policies, targets and strategies to address the requirements of international legislation. Develop programmes, promote } \\
\text { the waste hierarchy and best available techniques, introduce measures that value resources, and develop secondary materials } \\
\text { markets. Provide guidance, tools and support to encourage good practice, and promote long-term stability, eco-design and invest- } \\
\text { ment. Stimulate behaviour change by strengthening market confidence, developing measures to influence behaviour, and providing } \\
\text { reliable information. Information is collected and reviewed to measure progress with respect to targets and the success of imple- } \\
\text { mented measures and initiatives. }\end{array}$ \\
\hline $\begin{array}{l}\text { Government Depart- } \\
\text { ments \& Non-Gov. } \\
\text { Public Bodies }\end{array}$ & $\begin{array}{l}\text { Enforce regulatory frameworks and provide other regulatory functions to control relevant activities, develop programmes and tools, } \\
\text { and provide guidance for the delivery of zero waste plans and policies. Enable efficient resource use. Encourage investment in } \\
\text { innovative technologies. Contribute to the design of non-waste facilities / activities. Provide evidence to consultations and macro } \\
\text { level studies. }\end{array}$ \\
\hline Regional & $\begin{array}{l}\text { Adhere to regulatory frameworks. Develop programmes and strategic waste infrastructure plans with neighbouring regions. Provide } \\
\text { leadership in areas of influence and to achieve value for money with respect to procurement. Provide evidence for consultations, } \\
\text { adhere to audits, report data, and contribute to relevant planning applications. }\end{array}$ \\
\hline Waste Sector & $\begin{array}{l}\text { Adheres to regulatory frameworks. Partial responsibility for compliance. Responsibility regarding investment in capacity and infra- } \\
\text { structure considering national policy. Develop good practice commitments. Adhere to audits, and report information concerning } \\
\text { compositional data, services provided, and voluntary opportunities. Increase workplace skills. Public engagement. }\end{array}$ \\
\hline $\begin{array}{l}\text { Other Business \& } \\
\text { Industry }\end{array}$ & $\begin{array}{l}\text { Adhere to regulatory frameworks. Responsibility for investment in capacity and infrastructure considering national policy. Subject to } \\
\text { sector-specific programmes. Adhere to good practice commitments. Develop innovative technologies. Responsibility for reducing } \\
\text { waste generated under their control through resource efficiency opportunities and the incorporation of sustainable thinking into } \\
\text { product/service design. Provide evidence to consultations. Participate in awareness campaigns. Improve understanding and usage } \\
\text { of resources. }\end{array}$ \\
\hline Consumers & $\begin{array}{l}\text { Active participation in programmes and initiatives. Provide evidence to consultations. Involvement in waste infrastructure planning } \\
\text { process. Increase understanding of consumption and waste generation. Recognise and take responsibility for the waste generated. } \\
\text { Implored to be enthusiastic and take action. }\end{array}$ \\
\hline
\end{tabular}

Perhaps the starkest difference between the four documents was the inclusion of consumers, or lack thereof, where they held no responsibilities within the English document other than to receive waste management services and potentially participate in initiatives and information collection schemes. This contrasts with the Welsh and Scottish documents that, to varying degrees, hold the consumer responsible for their level of consumption and waste generation, and asks them to actively engage and participate in waste reduction programmes.

With respect to industry and business groups, Scotland and Wales encouraged greater engagement with CE ideals when compared to England and NI. Within the former, industry and business were asked to be innovative, and were encouraged to develop and take opportunities that would incorporate $\mathrm{CE}$ thinking into their business models. In contrast, in England and $\mathrm{Nl}$ engagement with industry and business was limited to providing policy, regulation and voluntary agreements (these were present in all documents) to which business and industry should adhere. Interestingly, NI placed an emphasis on the role of business and the implementation of environmental management systems to 
TABLE 5: Stakeholder responsibilities within Towards Zero Waste, One Wales: One Planet.

\begin{tabular}{|c|c|}
\hline Stakeholder & Responsibilities \\
\hline International & Set overarching legislation and objectives. Introduce broad programmes to assist with meeting objectives. \\
\hline National & $\begin{array}{l}\text { Transpose international legislation and objectives. Provide a long-term vision to reduce Wales' ecological footprint to within } \\
\text { environmental limits. Apply key principles (precautionary principle, polluter pays principle, proximity principle, waste hierarchy, and } \\
\text { equality of opportunity). Set domestic targets and sector-specific objectives. Introduce penalties for non-compliance. Grant pow- } \\
\text { ers to regulators for enforcement. Explore initiatives. Develop sector plans (including voluntary targets). Raise awareness. Provide } \\
\text { advice and support regarding secondary materials markets, IPP, and waste infrastructure. Promote broader themes of zero-waste, } \\
\text { sustainable development and citizen empowerment. Collect and publish data. Monitor indicators of progress (ecological footprint } \\
\text { of waste, provision of recycling services, destination of recyclates, outcomes of eco-design programmes, wellbeing, employment, } \\
\text { and skills). }\end{array}$ \\
\hline $\begin{array}{l}\text { Government Depart- } \\
\text { ments \& Non-Gov. } \\
\text { Public Bodies }\end{array}$ & $\begin{array}{l}\text { Ensure and enforce compliance. Develop and implement campaigns. Support local capacity/infrastructure plans and skills } \\
\text { development. Provide information on technical requirements. Assess skills gaps. Consult on legislation. Encouraged to adopt } \\
\text { sustainable waste management practises and drive change through procurement. }\end{array}$ \\
\hline Regional & $\begin{array}{l}\text { Provide waste collection services and implement engagement campaigns. Support alternatives to landfill and encourage systems } \\
\text { that treat waste as a resource to ensure greater consistency in recycled materials. Collect and report data to evaluate progress } \\
\text { towards waste prevention goals, best practice, and value for money. }\end{array}$ \\
\hline Waste Sector & $\begin{array}{l}\text { Adhere to legislation. Implement waste strategy. Provide waste collection services. Introduce programmes/initiatives that pro- } \\
\text { mote closed loop recycling. Assess infrastructure requirements. Establish integrated networks of waste facilities. Address skills } \\
\text { gaps and increase the number of green jobs. }\end{array}$ \\
\hline $\begin{array}{l}\text { Other Business \& } \\
\text { Industry }\end{array}$ & $\begin{array}{l}\text { Implement waste strategy. Adhere to sector specific plans (and achieve sector-specific targets). Develop and implement voluntary } \\
\text { arrangements that consider the polluter pays principle, extended producer responsibility and IPP. Exert influence through pro- } \\
\text { curement activity. Employ eco-design to reduce product impacts (including use of recycled/alternative materials and avoiding the } \\
\text { generation of legacy wastes). Contribute to feedback mechanism by recording and submitting data. Assessing skills gaps within } \\
\text { their own sector. Share responsibility for waste generated and future proof against future resource competition. }\end{array}$ \\
\hline Consumers & $\begin{array}{l}\text { Encouraged to develop local exchange schemes and participate in national educational and engagement schemes. Workers are } \\
\text { encouraged to recognise and rethink their influence within the workplace and at home regarding procurement and consumption. } \\
\text { Contribute to the well-being of Wales, resource efficiency and waste reduction. }\end{array}$ \\
\hline
\end{tabular}

TABLE 6: Stakeholder responsibilities within the Northern Ireland Delivering Resource Efficiency plan.

\begin{tabular}{|c|c|}
\hline Stakeholder & Responsibilities \\
\hline International & $\begin{array}{l}\text { Set overarching legislation and objectives. Introduce broad programmes to assist with meeting objectives. Provide access to } \\
\text { officials to support implementation of programmes and objectives. Identify financial and non-financial opportunities. }\end{array}$ \\
\hline National & $\begin{array}{l}\text { Ensure compliance with international policy. Develop (all-island) compatible and complementary policy. Participate in international } \\
\text { and UK initiatives. Propose sector-specific targets. Develop domestic re-use and voluntary quality assurance schemes. Reduce } \\
\text { burdens on business and support resource efficiency. Collect and publish information on waste flows, commodity prices, and } \\
\text { legislative proposals. }\end{array}$ \\
\hline $\begin{array}{l}\text { Government Depart- } \\
\text { ments \& Non-Gov. } \\
\text { Public Bodies }\end{array}$ & $\begin{array}{l}\text { Develop, monitor and enforce waste management strategy and accompanying policies and regulations. Use a suite of penalties } \\
\text { and sanctions to ensure compliance. Grant funds for schemes and initiatives. Develop programmes and educational campaigns. } \\
\text { Explore and exploit economies of scales. Support market development. Promote collaboration. Provide information. Instrumental } \\
\text { in consulting on strategies, legislation and spatial aspects. }\end{array}$ \\
\hline Regional & $\begin{array}{l}\text { Adhere to national and international legislation. Use powers to improve the quality of the environment. Responsible for planning } \\
\text { aspects of waste management strategies. Work in partnership with regulators, other regional stakeholders and the third sector to } \\
\text { tackle poor compliance, develop schemes and initiatives, and provide advice. Collect and report data. Provide evidence to consul- } \\
\text { tations and participate in studies, campaigns and inspections. }\end{array}$ \\
\hline Waste Sector & $\begin{array}{l}\text { Adhere to national and international legislation and permit/ licence conditions. Deliver domestic targets and actions. Develop and } \\
\text { utilise programmes and investment schemes to introduce innovative waste collection schemes and integrate facilities on an all-is- } \\
\text { land basis. Implement codes of practice. Support local authorities and communities to adhere to the waste hierarchy. Contribute } \\
\text { to consultations. Collect and report data regarding specific waste streams. }\end{array}$ \\
\hline $\begin{array}{l}\text { Other Business \& } \\
\text { Industry }\end{array}$ & $\begin{array}{l}\text { Adhere to national and international legislation, and sector specific domestic targets. Develop and participate in voluntary initia- } \\
\text { tives. Build market confidence. Consider best available techniques. }\end{array}$ \\
\hline Consumers & $\begin{array}{l}\text { Participate in campaigns. Promote social enterprise along with green jobs. Instigate improvement through public engagement and } \\
\text { social acceptance. }\end{array}$ \\
\hline
\end{tabular}

improve environmental performance, where this consideration did not feature in the other strategies.

\subsection{Implementation of EU policy and future implica- tions}

Analysis of these four documents illustrates point made by Garcia Quesada (2014) that the amount of discretion given to member states to implement EU objectives can lead to significant differences (and success) in national implementation. Where England has transposed EU policy with "no gold-plating" (minimum requirements), Wales in particular can be argued to have had more suc- cess in using the "gold-plating" (going beyond minimum requirements) approach (Anker et al.,, 2015). Indeed, it is noted that the English document incorporates and combines existing policy into one document without introducing new approaches. This is fundamentally different to Scotland, Wales and NI who all aim to set a strategic direction. Having said that, while NI does set a strategic direction, like England, its emphasis remains on meeting the requirements set out by the EU. In comparison, Scotland and Wales appear much more proactive, extending their strategies beyond EU requirements, influencing policy not in their direct control to achieve their individual goals, 
and understanding the need for, and instigating, change. This observation agrees with Winans et al (2017) and Scotford and Robinson (2013), regarding the superiority of Welsh and Scottish environmental policy within the UK, in that the strategies they promote are more progressive, but like England and $\mathrm{NI}$ they continue to refer to overarching objectives set by the EU.

Differences in approach may have contributed to differing levels of success with respect to EU targets. This disagrees with Andrews and Martin (2010) who found no variation in waste management services between the four devolved administrations, attributing this to objectives being set at a supranational level (i.e. by the EU). Conversely, these findings agree with Falmer et al (2013) who noted marked differences in the management strategies employed by the four devolved nations, connecting this to a lack of clarity and direction within overarching waste policy. This analysis found that in the period since strategy publication (2010 for Scotland and Wales; 2013 for England and NI), both Scotland and Wales have implemented strategy that has reduced waste generation, increased recycling rates and reduced landfilling of $\mathrm{BMW}$, with Wales achieving a landfill rate reduction of over $50 \%$. In comparison, waste generation in England and $\mathrm{NI}$ has increased and varying results are reported for recycling and landfilling. In England, while the landfill rate has been reduced, the rate of recycling has plateaued, remaining at $44.2 \%$. Whereas in $\mathrm{NI}$, both recycling and landfill rates have increased. With respect to EU targets, all four nations have achieved the landfill directive of no more than 55\% BWM landfilled by 2016, and Wales has already surpassed the recycling rate target set by WFD of at least $50 \%$ by 2020 . While it could be suggested that Scotland and $\mathrm{NI}$ are progressing towards meeting this target, the plateauing of England recycling rate could suggest its current strategy may struggle.

Overall, limitations for all of the strategies are a continued focus on waste management rather than resource utilisation, and the reliance on EU targets and objectives to set national priorities. This issue may become more pertinent after Brexit due to an absence of overarching UK strategy, which would have previously been supplied by the EU. While it appears that Wales and Scotland do have longterm policy objectives (including to future proof and avoid 'lock in') and have started the process of incorporating waste management strategy into the broader context of resource management and sustainable development, this is generally absent from the English (and therefore overall UK) strategy. This lack of coherence in objectives and enforcement across the four devolved nations may lead to further complications in the future. As suggested by Scotford and Robinson (2013), diverging amendments enacted by devolved administrations may lead to increased fragmentation and disparity of UK environmental policy.

\section{CONCLUSIONS}

An alternative to the linear economy model, the CE has been advocated internationally as a solution to current unsustainable consumption patterns. It aims to reduce consumption, recirculate products and materials, and pre- vent environmental degradation. In response, the EU has developed the forthcoming CEP to provide more stringent objectives and targets, reiterate the waste hierarchy, promote industrial symbiosis and elevate the role of resource efficiency. As with previous EU strategies, member states will be required to transpose the CEP into national strategy and achieve its targets and objectives. While the CEP does provide the correct direction for member states to initiate a transition toward the $\mathrm{CE}$, it has also been criticised for its continued focus on waste management with too little emphasis on high priority waste hierarchy categories such as reduce and reuse.

This study developed a framework based on CE-related literature in which an overall CE definition was identified, along with the importance of R-imperatives (in particular the waste hierarchy) and stakeholder engagement. The framework was used to assess the current waste strategies of the four devolved UK nations (England, Scotland, Wales and NI). Differences in interpretation and implementation of current EU objectives were identified across the devolved nations, with Wales and Scotland promoting more progressive strategies and showing greater improvement regarding EU waste targets. This confirms the conclusion of previous studies that Wales and Scotland currently have the most progressive waste management strategy of the four devolved nations.

The future of waste management strategy in the UK, will be shaped by the CEP and potential ramifications of Brexit. In the short to medium term, adoption of the CEP will provide overarching objectives and targets for the UK due to transposition into national policy. Long term objectives will depend on changes implemented by the UK government. In addition, enforcement that has previously been supplied by the EU to ensure objectives and targets are met may not be present unless a UK wide enforcement system is adopted. This may become an area of contention if Scotland and Wales, who already promote progressive waste strategies, were to diverge further. To address this issue, it is imperative that strong cross-party support is gained for long-term CE objectives both within each devolved parliament and across the UK. This would prevent the return of waste strategy politicisation that was successfully overcome on joining the EU due to the primacy of European law.

\section{ACKNOWLEDGEMENTS}

This study was completed as part of a PhD programme, funded by a studentship to Carly Fletcher from Manchester Metropolitan University and Viridor Waste.

\section{REFERENCES}

Andrews, D. (2015). The circular economy, design thinking and education for sustainability. Local Economy, 30, (3), 305-315. doi:10.1177/0269094215578226.

Anker, H. T., de Graaf K. J., Purdy, R., and Squintani, L. (2015). Coping with EU environmental legislation: Transposition principles and practices. Journal of Environmental Law, 27, (1), 17-44. doi:10.1093/jel/equ033.

BP Collins. (2016). Brexit: Implications for Waste and Resources Legislation. Retrieved from The Energy Industries Council Website: http://www.eic-uk.co.uk/Documents/Files/Waste_Legislation_ Eng_Wales_landscape\%20(2).pdf. 
Burges Salmon. (2016). Effects of a Brexit on Environmental laws Habitats, Waste, Chemicals and Air. Retrieved from https://www. burges-salmon.com/-media/files/publications/open-access/effects_of_a_brexit_on_environmental_laws.pdf

Cherry, C. E. and Pidgeon, N. F. (2018). Is sharing the solution? Exploring public acceptability of the sharing economy. Journal of Cleaner Production, 195, 939-948. doi: j.jclepro.2018.05.278

Cole, C., Osmani, M., Quddus, M., Wheatley, A. and Kay, K. (2014). Towards a Zero Waste Strategy for an English Local Authority. Resources, Conservation and Recycling, 89, 64-75. doi: 0.1016/j. resconrec.2014.05.005

Corbin, J. and Staruss, A. (2008). Basics of Qualitative Research (3rd ed.): Techniques and Procedures for Developing Grounded Theory. Thousand Oaks, CA: Sage doi:10.4135/9781452230153.

Department for Environment Food \& Rural Affairs [DEFRA]. (2013) Waste Management Plan for England. Retrieved from UK Government Website: https://www.gov.uk/government/uploads/system/ uploads/attachment_data/file/265810/pb14100-waste-management-plan-20131213.pdf.

Department for Environment Food \& Rural Affairs [DEFRA]. (2017). Digest of Waste and Resource Statistics - 2017 Edition. Retrieved from UK Government Website: https://assets.publishing.service. gov.uk/government/uploads/system/uploads/attachment_data/ file/607416/Digest_of_Waste_and_Resource_Statistics_2017_ rev.pdf

Department for Environment Food \& Rural Affairs [DEFRA]. (2018). UK Statistics on Waste. Retrieved from UK Government Website: https://www.gov.uk/government/uploads/system/uploads/attachment_data/file/683051/UK_Statisticson_Waste_statistical_ notice_Feb_2018_FINAL.pdf.

Department of the Environment [DoE]. (2013). Delivering Resource Efficiency. Retreived from the Department of Agriculture, Enviroment and rural Affairs - Northern Ireland Website: https://www.daera-ni. gov.uk/sites/default/files/publications/doe/waste-policy-delivering-resource-efficiency-northern-ireland-waste-management-strategy-2013.pdf.

European Commission [EC]. (1994). European Parliament and Council Directive 94/62/EC of 20 December 1994 on packaging and packaging waste. Retrieved from http://eur-lex.europa.eu/legal-content/EN/TXT/?uri=CELEX:01994L0062-20150526

European Commission [EC]. (1999). Council Directive 1999/31/EC of 26 April 1999 on the landfill of waste. Retrieved from https://eurlex.europa.eu/legal-content/EN/TXT/?uri=celex\%3A31999L0031

European Commission [EC]. (2005). Thematic Strategy on the sustainable use of natural resources. Retrieved from http://eur-lex.europa.eu/legal-content/EN/TXT/PDF/?uri=CELEX:52005DC0670\&from $=\mathrm{EN}$.

European Commission [EC]. (2006). Regulation (EC) no 1013/2006 of the European Parliament and of the Council of 14 June 2006 on Shipments of Waste. Retrieved from https://eur-lex.europa. eu/legal-content/EN/TXT/?qid=1454069470717\&uri=CELEX:02006R1013-20180101

European Commission [EC]. (2008a) Directive 2008/98/EC of the European Parliament and of the Council of 19 November 2008 on waste and repealing certain Directives. Retrieved from http://eurlex.europa.eu/legal-content/EN/TXT/?uri=CELEX:32008L0098.

European Commission [EC]. (2008b). Sustainable Consumption and Production and Sustainable Industrial Policy Action Plan. Retrieved from http://eur-lex.europa.eu/legal-content/EN/TXT/PDF/?uri=CELEX:52008DC0397

European Commission [EC]. (2016). Integrated Product Policy (IPP). Retrieved from http://ec.europa.eu/environment/ipp/index_en.htm

European Commission [EC]. (2017). Implementation of the Circular Economy Action Plan. Retrieved from http://ec.europa.eu/environment/circular-economy/index_en.htm.

European Commission [EC]. (2018a). Draft Agreement on the withdrawal of the United Kingdom of Great Britain and Northern Ireland from the European Union and the European Atomic Energy Community. [Position Paper]. Retrieved from: https:// ec.europa.eu/commission/publications/draft-agreement-withdrawal-united-kingdom-great-britain-and-northern-ireland-european-union-and-european-atomic-energy-community-0_en

European Commission [EC]. (2018b). Proposal for a directive of the European Parliament and of the Council amending Directive 1999/31/EC on the landfill of waste. Retrieved from: http://eur-lex. europa.eu/legal-content/EN/TXT/?uri=CELEX:52015PC0594
European Commission [EC]. (2018c). Proposal for a directive of the European Parliament and of the Council amending Directive 94/62/EC on packaging and packaging waste. Retrieved from: http://eur-lex.europa.eu/legal-content/EN/TXT/?uri=CELEX52015PC0596

European Commission [EC]. (2018d). Proposal for a directive of the European Parliament and of the Council amending Directive 2008/98/EC on waste. Retrieved from: http://eur-lex.europa.eu/ legal-content/EN/TXT/?uri=CELEX:52015PC0595

Elo, S. and Kyngäs, H. (2008). The qualitative content analysis process. Journal of Advanced Nursing, 62, 107-115. doi:10.1111/j.13652648.2007.04569.x.

Ellen MacArthur Foundation [EMF]. (2015). What is the circular economy? Retrieved from https://www.ellenmacarthurfoundation.org/ circular-economy.

Erkman, S. (1997). Industrial ecology: an historical view. Journal of Cleaner Production, 5, (1-2), 1-10.

Foxon, T. J. (2002). Technological and institutional 'lock-in' as a barrier to sustainable innovation. ICCEPT Working Paper, November 2002. Retrieved from http://www.iccept.ic.ac.uk/public.html

Fischer, C. J. (2011). The development and achievements of EU waste policy. Materials Cycles and Waste Management, 13, (1), 2-9. doi:10.1007/s10163-010-0311-z.

García Quesada, M. (2014). The EU as an "enforcement patchwork": the impact of national enforcement for compliance with EU water law in Spain and Britain. Journal of Public Policy, 34, (2), 331-353. doi:10.1017/S014384X13000238.

Gharfalkar, M., Court, R., Campbell, C., Ali, Z., and Hillier, G. (2015) Analysis of waste hierarchy in the European waste directive 2008/98/EC. Waste Management, 39, 305-313. doi: 10.1016/j. wasman.2015.02.007

Ghisellini, P., Cialani, C. and Ulgiati, S (2016). A review on circular economy: the expected transition to a balanced interplay of environmental and economic systems. Journal of Cleaner Production, $114,11-32$.

House of Lords (2017). Brexit: environment and climate change. HL Paper 109. London, The House of Lords. Retrieved from https://publications.parliament.uk/pa/ld201617/Idselect/ldeucom/109/109. pdf

Jawahir, I. S. and Bradley, R. (2016). Technological Elements of Circular Economy and the Principles of 6R-Based Closed-loop Material Flow in Sustainable Manufacturing. Procedia CIRP, 40, 103-108. doi:10.1016/j.procir.2016.01.067.

Kirchherr, J., Reike, D., and Hekkert, M. (2017). Conceptualizing the circular economy: An analysis of 114 definitions. Resources, Conservation and Recycling, 127, 221-232. doi: 10.1016/j.resconrec.2017.09.005

Lemiengre, J., de Casterle, B. D., Denier, Y., and Schotsmans, P. (2008). How do hospitals deal with euthanasia requests in Flanders (Belgium)? A content analysis of policy documents. Patient Education and Counselling, 71, 293-301. doi:10.1016/j. pec.2007.12.010.

Lieder, M. and Rashid, A. (2016). Towards circular economy implementation: a comprehensive review in context of manufacturing industry. Journal of Cleaner Production, 115, 36-51. doi:10.1016/j. jclepro.2015.12.042.

Maczka, K., Matczak, P., Pietrzyk-Kaszyńska, A., and Rechciński, M. (2016). Application of the ecosystem services concept in environmental policy - A systematic empirical analysis of national level policy documents in Poland. Ecological Economics, 128, 169-176. doi:10.1016/j.ecolecon.2016.04.023

Martin, C. J. (2016). The sharing economy: A pathway to sustainability or a nightmarish form of neoliberal capitalism? Ecological Economics, 121, 149-159. doi: j.ecolecon.2015.11.027

Mazzanti, M. and Zoboli, R. (2009). Municipal Waste Kuznets Curves: Evidence on Socio-Economic Drivers and Policy Effectiveness from the EU. Environmental and Resources Economics, 44, 203-. doi:10.1007/s10640-009-9280-x

McGlone, A. (2018, March). International trade implications of Brexit for the waste sector. Presentation at the UKELA / ESA / CIWM Seminar: Waste and the Circular Economy after Brexit, London, UK.

Meadows, D. H., Meadows, D. I., Randers, J., Behrens III, W. W. (1972) The Limits to Growth: A Report to The Club of Rome. Universe Books, NY 
Moreno, M., De los Rios, C., Rowe, Z., Charnley, F. (2016). A Conceptual Framework for Circular Design. Sustainability, 8, 937-951. doi:10.3390/su8090937.

Murray, A., Skene, K., and Haynes, K. (2017). The Circular Economy: An Interdisciplinary Exploration of the Concept and Application in a Global Context. Journal of Business Ethics, 140, 369-380.

Natural Scotland (2010). A Zero waste Plan for Scotland, The Scottish Government (Ed.), Edinburgh. Retreived from The Scottish Government Website: http://www.gov.scot/Resource/ Doc/314168/0099749.pdf.

Nilsson, M., Zamparutti, T., Petersen, J. E., Nykvist, B., Rudberg, P., and McGuinn, J. (2012). Understanding Policy Coherence: Analytical Framework and Examples of Sector-Environment Policy Interactions in the EU. Environmental Policy and Governance, 22, (6), 395423. doi:10.1002/eet.1589.

Paoli, L., Adriaenssen, A., Greenfield, V. A., and Conickx, M. (2017). Exploring Definitions of Serious Crime in EU Policy Documents and Academic Publications: A Content Analysis and Policy Implications. European Journal on Criminal Policy and Research, 23, (3), 269-285. doi:10.1007/s10610-016-9333-y.

Pearce, D. W and Turner, R. K. (1990). Economics of natural resources and the environment. John Hopkins University Press, Baltimore.

Peng, H. T. and Liu, Y. (2016). A comprehensive analysis of cleaner production policies in China. Journal of Cleaner Production, 135, 1138-1149. doi:10.1016/j.jclepro.2016.06.190.

Pomberger, R, Sarc. R, and Lorber, K. E. (2016). Dynamic visualisation of municipal waste management performance in the EU using Ternary Diagram method. Waste Management, 61, 558-571. doi:10.1016/j.wasman.2017.01.018.

Potting, J., Hekkert, M., Worrell, E., and Hanemaaiher, A. (2017). Circular Economy: Measuring Innovation in the Product Chain. Retrieved from http://www.pbl.nl/sites/default/files/cms/publicaties/pbl-2016-circular-economy-measuring-innovation-in-product-chains-2544.pdf

Price, J.L. (2001). The landfill directive and the challenge ahead: demands and pressures on the UK householder. Resource Conservation and Recycling, 32, 333-348. doi:10.1016/S09213449(01)00070-2.

Reike, D., Vermeulen,W. J. V. and Witjes, S. (2018). The circular economy: New or Refurbished as CE 3.0? - Exploring Controversies in the Conceptualization of the Circular Economy through a Focus on History and Resource Value Retention Options. Resources, Conservation and Recycling, 135, 246-264.

Scotford, E. and Robinson, J. (2013). UK Environmental Legislation and Its Administration in 2013-Achievements, Challenges and Prospects. Journal of Environmental Law, 25, (3), 383-409. doi:10.1093/jel/eqt023

Stahel. W, R. (2016). Circular economy. Nature, 531, (7595), 435 (comment)

Stahel, W., Reday-Mulvey, G. (1976). The potential for substituting manpower for energy, Report to the Commission of the European Communities, Brussels, (published as Stahel, W.R. and Reday-Mulvey, G. (1981), Jobs for Tomorrow, New York, Vantage Press).
Su. B, Heshmati. A, Geng. Y, and Yu. X. (2013). A review of the circular economy in China: moving from rhetoric to implementation. Journal of Cleaner Production, 42, 215. doi:10.1016/j.jclepro.2012.11.020

Testa, F., Grappio, P., Gusmerotti, N.M., Iraldo, F. and Frey, M. (2016). Examining green public procurement using content analysis: existing difficulties for procurers and useful recommendations. Environment, Development and Sustainability, 18, (1), 197-219. doi:10.1007/s10668-015-9634-1

Tukker, A. (2015). Product services for a resource-efficient and circular economy - A review. Journal of Cleaner Production, 97, 76-91. doi:10.1016/j.jclepro.2013.11.049

United Kingdom Environmental Law Association [UKELA]. (2016). Brexit - Implications of the UK leaving the European Union: Waste Management. Retrieved from United Kingdom Environmental Law Association Website: https://www.ukela.org/content/page/5640/ Brexit\%20Waste\%20Management\%20WP.pdf.

United Kingdom Environmental Law Association [UKELA]. (2017). Brexit and Environmental Law: The UK and International Law after Brexit. Retrieved from United Kingdom Environmental Law Association Website: https://www.ukela.org/content/doclib/320.pdf.

United Nations Environment Programme [UNEP]. (1989). Basel Convention on the control of transboundary movements of hazardous wastes and their disposal. Retrieved from http://www.basel.int

United Nations Environment Programme [UNEP]. (2015). The 10-year framework of programmes on Sustainable Consumption and Production. Retrieved from United Nations Environment Programme Website: http://www.unep.org/10yfp/Portals/50150/10YFP\%20 Brochure\%20English.pdf.

Van Ewijk, S. and Stegemann, J. A. (2016). Limitations of the waste hierarchy for achieving absolute reductions in material throughput. Journal of Cleaner Production, 132, 122-128. doi: 10.1016/j.jclepro.2014.11.051

Veleva, V., Bodkin, G. and Todorova, S. (2017). The need for better measurement and employee engagement to advance a circular economy: Lessons from Biogen's "zero waste" journey. Journal of Cleaner Production, 154, 517-529.

Welsh Assembly Government [WAG]. (2010). Towards Zero Waste - One Wales: One Planet. Retrieved from Welsh Assemby Government Website: http://gov.wales/docs/desh/publications/100621 wastetowardszeroen.pdf

Welsh, E. (2002). Dealing with Data: Using NVivo in the Qualitative Data Analysis Process. Forum: Qualitative Social Research, 3, (2), Art. 26. doi: $10.17169 /$ fqs -3.2 .865$

Winans, K., Kendall, A. and Deng, H. (2017). The history and current applications of the circular economy concept. Renewable and Sustainable Energy Reviews, 68, 825-833. doi:10.2016/j. rser.2016.09.123

Wysokińska, Z. (2016). The "New" Environmental Policy of the European Union: A Path to Development of a Circular Economy and Mitigation of the Negative Effects of Climate Change. Comparative Economic Research: Central and Eastern Europe, 19(2), 57. doi:10.1515/cer-2016-0013 